Article

\title{
Does Foreign Direct Investment Crowd in or Crowd out Domestic Investment in South Africa? An ARDL-ECM Approach
}

\author{
Author: Dumisani Pamba \\ ${ }^{1}$ School of Accounting, Economics and Finance, University of KwaZulu-Natal, Westville, Durban, 4000. \\ South Africa, 217076475@stu.ukzn.ac.za \\ *Correspondence: 217076475@stu.ukzn.ac.za
}

\begin{abstract}
The aim of this study is to empirically examine the link between foreign direct investment (FDI) and domestic investment (DI) in South Africa over the period of 41 years (1975-2016). Accurately, it attempts to determine whether FDI crowds in or crowds out DI in South Africa. DI is sub-divided into private domestic investment (credit to domestic private sector) and public corporation investment (state owned enterprises). We used the Autoregressive Distributed Lag-Error Correction Model (ARDL-ECM) technique to ascertain long run and short run effects concurrently after establishing that the variables were stationary (using the PP test). The results of the unit root test shows that all variables are integrated of order zero $\mathrm{I}(0)$ or integrated of order one I(1), indicating that the series of variables are stationary in the level or first difference form. The findings revealed that variables are cointegrated in the long run. The ARDL model found a negative link between FDI and domestic investment. The result implies that FDI crowds out domestic investment. Moreover, the long run estimate revealed that domestic investment is crowded in by government investment expenditure (GINV). Other findings uncovered that, GDP crowds out private domestic investment while crowding in public corporation investment. Moreover, the long run estimate revealed that domestic investment is crowded in by gross domestic savings (SAV). On the other hand, the real exchange rate (EXCR) crowds out private domestic investment while crowding in public corporation investment. Trade openness (TRA) crowds out domestic investment. Additionally, the short run estimate uncovered that private domestic investment is crowded out by FDI, EXCR, and TRA whereas GINV, GDP and SAV is crowding in private domestic investment. Other findings discovered that, in the short run, public corporation investment is crowded out by FDI, GDP, EXCR and TRA, while GINV and SAV crowd in public corporation investment. The CUSUM confirms that the models are structurally firmness.
\end{abstract}

Keywords: FDI; Domestic Investment; Government Investment Expenditure; Economic Growth; Real exchange rate; Gross Domestic Savings; Trade openness; ARDL-ECM Approach and South Africa

\section{Introduction}

In the economic literature, the link between foreign direct investment (FDI) and domestic investment (DI) is a contentious subject matter in recent years. One of the most contentious issues is whether FDI crowds in or crowds out homegrown investment. On the other side, the question is whether FDI has a positive spillover effect on domestic investment in the host country. These spillovers and externalities are known to happen in a variety of ways. At first, spillover may occur as a result of workers migration when well-trained workers of foreign firms start their own businesses or work for locally held businesses. Then, as a result of their training, these individuals will bring managerial and technology skills and knowledge with them, which will aid to spread out spillover effects. Second, the presence of multinationals (MNEs) 
may lead to the "demonstration effect," which is the spread of information about new modern industrial processes. According to Jude (2016) and Liu (2008), FDI acts as a vehicle for technology transfer, resulting in overall technological innovation and productivity spillovers in host nations. Third, foreign firms may improve the host country's production efficiency by forming partnerships with domestic firms (see Rodriguez-Clare, 1996). Lastly, foreign enterprises create industry rivalry, which is frequently beneficial to indigenous firms, resulting in a "crowding in" impact.

Many empirical studies have looked at the linkage between FDI and domestic investment. Bosworth et al. (1999); Xu and Wang (2007); Tang et al. (2008); Chang (2010) and Farla et al. (2014) are some examples of studies that find positive effects of FDI on domestic investment, while other studies found that FDI had no significant effect on home-grown investment and even crowded out domestic capital accumulation and innovation. FDI inflows crowd out homegrown investment, according to studies by Adams (2009); Agosin and Machado (2005); Morrissey and Udomkerdmongkol (2012) and Ashraf and Herzer (2014). Blomstrom, Kokko, and Zejen (2000) believe that multinational corporations' crowding-out effect is more severe in developing nations than in advanced nations. As per Sağlam and Yalta (2011), there is no link between FDI inflows and domestic investment. According to Agosin and Machado (2005) and Wang (2010), FDI inflows have a neutral, crowding-in, or crowding-out effect on home-grown investment, depending on the country's economic structure, macroeconomic dynamics, and the firm's underlying incentives to invest overseas. In Aitken and Harrison's (1999) study, they discovered that FDI increases output within the receiving plants but decreases output in domestically owned plants, contradicting spillover theory. Based on these considerations, the effect of FDI on domestic investment is a contentious and unresolved subject.

FDI inflows into the South African economy are inextricably linked to the country's historical isolation. Prior to 1994, only a small share of global FDI flows to emerging nations went to South Africa. The country's connectivity to global investment and production chains was minimal, and FDI and trade in parts and components had a relatively limited role in the country's economy. Inward FDI flows into South Africa have not been able to achieve the levels seen in similar Asian and Latin American nations after the country's democratic transition in 1994 (Wocke and Sing, 2013). This low amount of FDI, according to the authors, is partially owing to South Africa's "dual economy" of cutting-edge capital markets and industrial evolution in some sectors of the economy however with steady redundancy and policy susceptibility.

Since capital formation happens when the host country's domestic cycle of production, income, and savings is working, domestic investment plays a strategic role. As a result, the ability to generate domestic capital shows the presence of a stable economic climate and attractive prospects for investors, both local and international. South Africa's domestic investment, both public and private, has been quite low in recent years.

Domestic investment, which includes both private and public investment, is a critical component of overall investment for most economies, particularly emerging nations, according to Olise et al. (2013). According to Ullah et al., (2014), improved private investment indicates a good return on investment in the home-grown economy, but increased public investment indicates infrastructure improvement and hence lowers the cost of doing business. Ullah et al., (2014) further suggest that these two functions of domestic investment encourage foreign investors to take advantage of high returns. The influence of FDI on domestic investment in South Africa, on the other hand, is equivocal; FDI may crowd out or crowd in homegrown investment. The crowding out effect of FDI means it is insignificant in South Africa, while the crowding in effect of FDI on domestic investment is favorable to the country.

As a result, this study aims to contribute to the growing body of knowledge about foreign direct and domestic investment, making it relevant in the field of international finance. Given that the quest for economic growth drivers is far from over, this study will be important in determining whether FDI crowds in or crowds out domestic investment in South Africa. The study specifically aims to look at the overall impact of FDI on domestic investment in South Africa, and whether it supplements or substitutes the 
country's existing domestic capital during the sample period. We look into whether South Africa's increased efforts to attract and benefit from FDI over the years has had an impact on domestic investment.

The paper is arranged as follows after the introduction in Section 1: The literature review is presented in Section 2, and the data, model description, and technique are discussed in Section 3. Section 4 presents and examines the empirical findings, and Section 5 draws the study to a conclusion.

\section{Literature review}

\subsection{Empirical Studies.}

Despite the abundance of literature on FDI, the relationship between FDI and domestic investment has gotten shockingly little attention in the economic literature thus far. Theoretical studies are few, while empirical presentations yield a variety of results, as indicated below.

For the case of Nigeria, Gungor and Ringim (2017) investigated the association between FDI, domestic investment (DI), and economic growth. The study applied annual time series data from 1980 to 2015. The approaches used were the Johansen multivariate cointegration test and the vector error correction model (VECM) estimate. According to the study's Johansen cointegration finding, FDI, domestic investment, and economic growth share a long-run equilibrium connection.

Shawa and Amoro (2014) employed co-integration and the Granger Causality test to analyze the causal relationship between foreign direct investment, GDP growth, domestic investment, and export in Kenya from 1980 to 2013. The co-integration test findings show that the four variables studied in this study (FDI, GDP growth, domestic investment, and exports) have a long-term connection.

Furthermore, Lean and Tan (2010) utilized annual time series data from 1970 to 2009 to examine correlations between FDI, domestic investment, and economic development in Malaysia. The technique used is vector autoregressive (VAR). The study's empirical findings suggest that an increase in FDI has a favorable influence on domestic investment. This means that FDI crowds in domestic investment and that FDI and domestic investment have a complimentary impact.

The findings of the Ordinary Least Squares (OLS) estimation suggest that domestic investment has the highest level of positive effect on FDI inflow, according to Paolino (2009), who utilizes data from China from 1977 to 2007. Adams (2009), on the other hand, looked examined the link between FDI, domestic investment, and economic growth for a panel of 42 SSA nations from 1990 to 2003. The analysis demonstrates a significant negative effect of current period FDI on domestic investment using both OLS and fixed effects estimation approaches, but a significant positive effect of lagged FDI on domestic investment using both estimation methods. As a result, the findings of this study reveal that FDI has an early crowding-out effect on local investment, followed by a later crowding-in effect.

Ndikumana and Verick (2008) look at 38 countries in Sub-Saharan Africa from 1970 to 2005 and find a crowding-in impact between FDI and domestic investment. Ullah et al. (2014) look at the relationship between FDI, domestic investment, and growth in their study. The findings of this study suggest that foreign direct investment (FDI) can complement domestic investment and vice versa.

Tan and Tang (2016) used the Johansen-Juselius cointegration method and the Granger causality method to investigate the long-term link between domestic investment, FDI, trade, interest rates, and economic growth in the ASEAN-5 regions from 1970 to 2012. For the ASEAN-5, the findings demonstrated the existence of long-term causal links between local investment and FDI.

Jan and Vladimr (2014) looked at whether FDI crowds in or crowds out domestic investment in the Czech Republic, Hungary, and Poland. For the period 1990-2000, the data revealed that there was evidence of a crowding-out effect in Poland. They discovered a crowding-in effect in Hungary between 1990 and 2000, and in the Czech Republic between 1993 and 2000. 
For the period 1978-79 to 2009-10, Badri Narayan Rath and Debi Prasad Bal (2014) looked at the dynamic interaction between Private Domestic Investment (PDI), Foreign Direct Investment (FDI), and Public Investment (PU) in India. The structural break points in the data series were determined using the Zivot and Andrews test. The results of the structural VAR model show that FDI crowds in PDI, whereas PU does not 'crowd out' or 'crowd in' PDI. They also discovered evidence that shocks in PU and PDI had improved FDI inflows into India.

Meanwhile, other academics combat combination bias by classifying countries based on their economic growth stage. Al-Sadig (2013), for example, divides a sample of 91 developing nations from 1970 to 2000 and finds evidence for the crowding-in hypothesis, however the degree of this effect is highly dependent on the availability of human capital in low-income nations.

Similarly, Apergis et al. (2006) empirically examine the linkages between FDI and domestic investment using annual data for 30 countries from America, Asia, Europe, and Africa from 1992 to 2002, and find a two-way causation between FDI and domestic investment as a consequence of bivariate causality tests and cointegration between FDI and domestic investment for all the selected country groups as a result of multivariate cointegration tests. For Asian and African nations, the bivariate model revealed a positive long-run association, but none for American and European countries. When American and European countries are considered, the crowding out effect becomes more prominent. The bivariate model results revealed a positive long-run association, with Asian and African countries showing a long-run association. In the multivariate model, however, there is no evidence for American and European nations. When American and European countries are evaluated, the crowding out effect becomes more prominent. In a similar line, Wang (2010) looked at 50 nations from 1970 to 2004 and found that FDI had a neutral effect on domestic investment in developed nations but a positive effect in developing countries.

In this literature, there are several examples of negative effects of FDI on domestic investment. For example, Ivanovi (2015) explored how FDI influences domestic investment in the Republic of Croatia utilizing quarterly time series data extending from Q1 2001 to Q4 2014 and processed with the subset VAR econometric model. With a temporal lag, the results show a negative association between FDI and domestic investment in the Republic of Croatia. In Ethiopia, Aboye (2017) looked at the relationship between foreign direct investment and domestic investment. A time series data collection from 1975 to 2014 was used, along with the Vector Error Correction Model (VECM) model. The findings revealed that FDI and private domestic investment have a crowding out effect. In other words, FDI has no impact on domestic investment in Ethiopia, both long and short term. In the same vein, Agosin and Mayer (2000) use panel data from 1970 to 1996 to investigate the extent to which FDI in developing countries crowds in or crowds out domestic investment. FDI crowds out domestic investment or fails to contribute to capital formation, according to the findings. Cristina (2015) tested the hypothesis of FDI-led capital accumulation in Central and Eastern European countries. Using a sample of 10 CEECs from 1990 to 2010, the study looks at the link between FDI and domestic investment. The findings show that FDI has a negative impact on domestic investment.

There have been conflicting results from the existing empirical research on the link between FDI and domestic investment. Inward FDI has either a positive or growing influence on domestic investment, or a negative or declining effect, according to empirical findings. Differences in the geographic regions (locations) covered, the level of development in a specific nation, existing economic circumstances and policies, the types of FDI inflow, and the econometric methodologies utilized all affect the influence of FDI on domestic investment. However, most studies agree that current economic conditions play a critical role in minimizing the spillovers of inbound foreign investments. In addition, when economic conditions in host countries/regions change, the impact of FDI on local investment will vary over time. 


\subsection{Research Gap}

This study aims to add to a country-specific examination of the dynamic links between foreign direct investment and domestic investment in South Africa. The majority of the extant literature publications on the impact of FDI on domestic investment use a variety of econometric methodologies, cover a variety of sample locations, and span a variety of time periods. Furthermore, due to the fact that each investigated region has varied economic conditions, the conclusions drawn from existing literature on the subject vary. This study intends to add to the existing literature by looking into the link between FDI and domestic investment in South Africa, based on evidence of growing efforts to attract more FDI. The majority of studies in South Africa focus on the influence of foreign direct investment on economic growth, which may overlook the process by which foreign direct investment might drive home-grown investment to crowd in or out. They only looked at the relationship between foreign direct investment and economic growth.

As a result, one of the most significant impact of this research was the recognition that foreign direct investment can influence the domestic investment process through a variety of channels, some of which are complements or substitutes for existing domestic capital in South Africa over the sample period. In this study, domestic investment is broken down into two categories: private domestic investment (credit to domestic private sector) and public corporations investment (state-owned enterprises). This enables us to investigate the link between private domestic investment and foreign direct investment, as well as the relationship between public corporations' investment and foreign direct investment. To my knowledge, there is no empirical literature in South Africa that has decomposed domestic investment into private domestic investment and public domestic investment by state-owned enterprises, as well as using domestic investment as a dependent variable in the study.

\section{Methodology.}

\subsection{Data Measurement and Source.}

This study examines the empirical link between foreign direct investment and domestic investment in South Africa, using annual time series data from the South African Reserve Bank (SARB) statistics bulletin spanning 41 years (1975-2016).

Table 1. Definition of the Variables in the Model

\begin{tabular}{ccc}
\hline Variables name & Variables description & Measures \\
\hline CPS & Total credit to domestic private sector & Domestic investment \\
PCI & Total public corporations investment & Domestic investment \\
FDI & Total foreign direct investment & Foreign direct investment \\
GINV & Total Government Investment expenditure & National government investment \\
GDP & Total real GDP per capita & Economic growth \\
EXCR & Real exchange rate & Effect of exchange rate \\
SAV & Gross domestic saving \% of GDP & Saving \\
TRA & Total exports and imports to GDP & Trade openness \\
\hline
\end{tabular}

Domestic investment is a dependent variable that is measured using credit to the private sector (CPS) and public corporations investment (PCI). Domestic investment, which includes both private and public investment, according to Olise et al. (2013), is a critical component of overall investment. FDI, on the other hand, FDI was defined by Onyinyechi and Ekwe (2017) as the net inflow of investment made to acquire a long-term stake (10 percent or more voting shares) in a business operating in a country other than the investor's. FDI and domestic investment are likely to have a negative connection. Foreign direct investment (FDI) at high levels is anticipated to reduce domestic investment. Government investment expenditure 
(GINV) refers to investments made by the national government that are not undertaken by public corporations. Infrastructure investment by the government is anticipated to attract domestic investment. The real GDP per capita (GDP) measures economic growth and is measured by dividing the entire population by the real GDP. We choose real GDP per capita because it incorporates the economic growth and welfare effects of South Africa's rising economy. GDP and private investment are projected to have a favorable association. As a result, an increase in GDP is predicted to boost the amount of domestic investment. The influence of exchange rates on economic growth is measured using a Real Exchange Rate (EXCR) (Fedderke and Romm, 2005). The EXCR is expected to have a beneficial impact on domestic investment, all things being equal, because a fall in the real value of the Rand (South African currency) boosts the competitiveness of domestic investment products overseas. GDP minus final consumption expenditure equals Gross Domestic Savings (SAV). It is represented as a percentage of gross domestic product (GDP). Gross domestic saving and domestic investment are expected to have a favorable connection. As a result, a rise in gross domestic savings is predicted to boost the amount of domestic investment. Finally, trade openness is measured as the ratio of total exports and imports to GDP, which represents an economy's degree of integration with global economic forces (Leamer, 1988; and Yen, 2008). Trade openness and domestic investment are predicted to have a negative connection. The presence of more imported goods than exported goods is projected to reduce domestic investment. All of the variables are converted to logarithms.

\subsection{Model Specification.}

The study hypothesized that foreign direct investment in South Africa is crowding out domestic investment. The dependent variable in the model is domestic investment (DI), whereas the independent variables are foreign direct investment (FDI), government investment expenditure (GINV), and real GDP per capita (GDP), real exchange rate (EXCR), gross domestic savings (SAV), and trade openness (TRA). This study used a simple model to examine the link between variables:

$$
\mathrm{DI}_{t i}=f\left(\mathrm{FDI}_{\mathrm{t}}, \mathrm{GINV}_{\mathrm{t}}, \mathrm{GPD}_{\mathrm{t}}, \mathrm{EXCR}_{\mathrm{t}}, \mathrm{SAV}_{\mathrm{t}}, \mathrm{TRA}_{\mathrm{t}}\right)
$$

In equation (1), the symbol i stand for private sector credit and public investment, while the subscript "t" stands for present time. When we linearize equation (1), we get:

$$
\ln \mathrm{DI}_{t i}=\alpha_{0}+\alpha_{1} \ln \mathrm{FDI}_{\mathrm{t}}+\alpha_{2} \ln \mathrm{GINV}_{\mathrm{t}}+\alpha_{3} \ln \mathrm{GDP}_{\mathrm{t}}+\alpha_{4} \ln \mathrm{EXCR}_{\mathrm{t}}+\alpha_{5} \ln \mathrm{SAV}_{\mathrm{t}}+\alpha_{6} \ln \mathrm{TRA}_{\mathrm{t}}+\mu_{\mathrm{t}}
$$

$\alpha 0$, is intercept, $\alpha 1$ to $\alpha 6$ are the slopes of the independent variable coefficients to be computed, and $\mu \mathrm{t}$ is the error term at time $t$.

\subsection{The ADRL Bounds Test.}

To rule out erroneous results in time series analysis, the model must have a significant cointegrated relationship among variables. Both bivariate and multivariate cointegration tests are frequently used to detect the long-run relationship among main variables of interest, according to Engle and Granger (1987). The multivariate cointegration test looks to be more efficient in theory since it identifies many cointegrating vectors. However, according to Ang (2009), such a test could be difficult to interpret if the model contains more than one cointegrating vector. Both bivariate and multivariate cointegration tests are ineffective when the model has heterogeneous integration orders.

The Autoregressive Distributed Lag (ARDL) bounds test, among others, is an alternative to the abovementioned cointegration tests. To test and establish the short-run and long-run relationships between the variables of interest and domestic investment, we will employ the popular ARDL bounds testing technique 
shaped by Pesaran et al. (2001) and Pesaran and Shin (1996). The ARDL approach has the benefit of handling integer or fractional order of integration and does not impose the restrictive premise that all variables under investigation must be integrated in the same order, therefore avoiding the need to test the order of integration of variables. Importantly, this strategy works whether the variables are all I(1) or a mix of I(0) and I(1). According to Pesaran and Shin (1996), this is an important factor since some variables may have a fractional order of integration. According to Narayan (2005), the ARDL technique has better small-sample properties than traditional cointegration tests. According to Pesaran and Shin (1998), a properly stated lag structure not only adjusts for serial correlation but also lowers the model's possible endogeneity. Finally, Baek (2016) suggested that by applying a simple linear transformation to the described ARDL model, we may create a dynamic unrestricted ECM (UECM), with the transformed UECM having the benefit of mixing short run dynamics with long-run equilibrium without sacrificing any substantial information.

On the basis of the previous justifications, we propose the following UECM of ARDL cointegration approach:

$$
\begin{gathered}
\Delta \ln \mathrm{DI}_{\mathrm{t}}=\beta_{0}+\sum_{i-1}^{n} \beta_{11} \Delta \ln \mathrm{DI}_{\mathrm{t}-1}+\sum_{i-1}^{n} \beta_{2 \mathrm{II}} \Delta \ln \mathrm{FDI}_{\mathrm{t}-1}+\sum_{i-0}^{n} \beta_{3 \mathrm{I}} \Delta \ln \mathrm{GINV}_{\mathrm{t}-1} \\
+\sum_{i-0}^{n} \beta_{4 \mathrm{II}} \Delta \ln \mathrm{GPD}_{\mathrm{t}-1}+\sum_{i-0}^{n} \beta_{5 \mathrm{i}} \Delta \ln \mathrm{EXCR}_{\mathrm{t}-1}+\sum_{i-1}^{n} \beta_{61} \Delta \ln \mathrm{SAV}_{\mathrm{t}-1}+\sum_{i-1}^{n} \beta_{7 \mathrm{I}} \Delta \ln \mathrm{TRA}_{\mathrm{t}-1}+\alpha_{1} \ln \mathrm{DI}_{\mathrm{t}-1}+\alpha_{2} \ln \mathrm{FDI}_{\mathrm{t}-1} \\
+\alpha_{3} \ln \mathrm{GINV}_{\mathrm{t}-1}+\alpha_{4} \ln \mathrm{GDP}_{\mathrm{t}-1}+\alpha_{5} \ln \mathrm{EXCR}_{\mathrm{t}-1}+\alpha_{6} \ln \mathrm{SAV}_{\mathrm{t}-1}+\alpha_{7} \ln \mathrm{TRA}_{\mathrm{t}-1}+\mu_{\mathrm{t}}
\end{gathered}
$$

$\mu$ t is the error term in equation 3, where $\Delta$ denotes the first difference, and the short and long run elasticities are $\beta_{1}, \ldots, \beta_{7}$ and $\alpha_{1}, \ldots, \alpha 7$, respectively.

We begin by testing the null hypothesis of the variables of interest in order to identify a long-run equilibrium connection between them $\mathrm{H}_{0}: \beta_{1}=\beta_{2}=\beta_{3}=\beta_{4}=\beta_{5}=\beta_{6}=\beta_{7}=0$ and the alternative hypothesis remains as $\mathrm{H}_{1}: \beta_{1} \neq \beta_{2} \neq \beta_{3} \neq \beta_{4} \neq \beta_{5} \neq \beta_{6} \neq \beta_{7} \neq 0$. The null hypothesis implies that there is no cointegration among variables, whereas the alternative hypothesis implies that there is cointegration among variables.

The F-test of the ARDL technique is used to assess if the variables are cointegrated. The null hypothesis of no cointegration is rejected if the F-statistic is greater than the upper bounds of the Narayan crucial bounds table, indicating that the variables have a long-run connection. If the F-statistic is smaller than the lower critical value of the Narayan critical boundaries table, however, the null hypothesis cannot be rejected, showing that the variables are not cointegrated. There is no conclusion on whether there is cointegration if the calculated F-statistic sits between the upper and lower bounds at a given significant level. In other words, the test is inconclusive. The long-run coefficients of the ARDL model may be calculated after examining the link between the variables:

$$
\begin{array}{r}
\Delta l n \mathrm{DI}_{\mathrm{t}}=\beta_{0}+\sum_{i-1}^{n} \beta_{1 \mathrm{I}} \Delta \ln \mathrm{DI}_{\mathrm{t}-1}+\sum_{i-1}^{n} \beta_{2 \mathrm{II}} \Delta \ln \mathrm{FDI}_{\mathrm{t}-1}+\sum_{i-0}^{n} \beta_{3 \mathrm{I}} \Delta \ln \mathrm{GINV}_{\mathrm{t}-1} \\
+\sum_{i-0}^{n} \beta_{4 \mathrm{II}} \Delta \ln \mathrm{GPD}_{\mathrm{t}-1}+\sum_{i-0}^{n} \beta_{5 \mathrm{i}} \Delta \ln \mathrm{EXCR}_{\mathrm{t}-1}+\sum_{i-1}^{n} \beta_{6 \mathrm{I}} \Delta \ln \mathrm{SAV}_{\mathrm{t}-1}+\sum_{i-1}^{n} \beta_{7 \mathrm{I}} \Delta \ln \mathrm{TRA}_{\mathrm{t}-1}+\mu_{\mathrm{t}}
\end{array}
$$

If the variables are cointegrated, the long run and short run models of equation 4 will be estimated using the usual OLS to determine the speed of return to equilibrium of domestic investment as well as the short run and long run coefficients. The error correction model described in equation 5 follows the long run model.

$$
\begin{aligned}
& \Delta \operatorname{lnDI} \mathrm{I}_{\mathrm{t}}=\beta_{0}+\sum_{i-1}^{n} \beta_{1 \mathrm{I}} \Delta \ln \mathrm{DI}_{\mathrm{t}-1}+\sum_{i-1}^{n} \beta_{2 \mathrm{I}} \Delta \ln \mathrm{FDI}_{\mathrm{t}-1}+\sum_{i-0}^{n} \beta_{3 \mathrm{I}} \Delta \ln \mathrm{GINV}_{\mathrm{t}-1}
\end{aligned}
$$

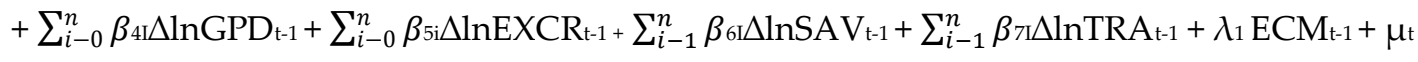


The short run speed of adjustment back to long run equilibrium is measured by the coefficient of the error correction term (ECM), which is $\lambda 1$. It shows how domestic investment deviates from long-run equilibrium but progressively returns to it.

To avoid spurious results, we first presented a unit root test on domestic investment (CPS and PCI), foreign direct investment (FDI), government investment expenditure (GINV), economic growth (GDP), exchange rate (EXCR), gross domestic savings (SAV), and trade openness (TRA). The unit root test was performed and the results are shown in Table 2.

\section{Results and Discussion.}

\subsection{The Unit Root Test.}

To determine the order of integration of the variables, the Phillips-Perron (PP) unit root test is utilized. The PP compares a unit root's null to the alternative of stationary. Table 2 shows that none of the variables are integrated at a higher order than one, implying that all of the series are of order I(1), with the exception of CPS, FDI, and SAV, which are of order I(1) (0). As a result, the ARDL bounds approaches can be used properly.

Table 2. Unit Root Results.

\begin{tabular}{ccccc}
\hline Variables & PP Test & Critical Value & Status & Remark \\
\hline $\ln \mathrm{CPS}$ & 5.821127 & $-3.600987^{*}$ & $\mathrm{I}(0)$ & Stationary \\
$\ln \mathrm{PCI}$ & -4.300407 & $-3.605593^{*}$ & $\mathrm{I}(1)$ & Stationary \\
$\ln \mathrm{FDI}$ & 7.171917 & $-3.600987^{*}$ & $\mathrm{I}(0)$ & Stationary \\
$\ln \mathrm{GINV}$ & -4.178289 & $-3.605593^{*}$ & $\mathrm{I}(1)$ & Stationary \\
$\ln \mathrm{GDP}$ & -4.054142 & $-3.605593^{*}$ & $\mathrm{I}(1)$ & Stationary \\
$\ln \mathrm{EXCR}$ & -5.402564 & $-3.605593^{*}$ & $\mathrm{I}(1)$ & Stationary \\
$\ln \mathrm{SAV}$ & 6.669178 & $-3.600987^{*}$ & $\mathrm{I}(0)$ & Stationary \\
$\ln \mathrm{TRA}$ & -5.375308 & $-3.605593^{*}$ & $\mathrm{I}(1)$ & Stationary \\
\hline
\end{tabular}

Note. $\left({ }^{*}\right)$, indicate significant at $1 \%$. All the variables are log linearized. Source: Authors' computation

We now run the ARDL bounds test after confirming that all of our variables are integrated of either $\mathrm{I}(0)$ or I(1).

\subsection{Optimal Lag Selection and Cointegration test results}

\section{MODEL I}

The optimal lag must be determined before the ARDL can be estimated. Based on the number of regressors included in the CPS model, the maximum lag length selected by Akaike information criterion (AIC) is 1 . As a result, the ARDL domestic investment (as measured by credit to the private sector) model is ARDL $(1,1,1,0,0,0,0)$. Using the ARDL approach to cointegration test, we computed the F-statistic using the ordinary least square (OLS) technique. Tables 3 shows the F-statistics calculated for the cointegration test. At a 1\% level of significance, the F-statistic for the first model (5.904274, Table 3) is higher than the Narayan (2005) table's upper bounds value (3.99). This demonstrates that the variables have a long-run association. 
Table 3. F-Bounds Test

\begin{tabular}{ccccc}
\hline Test Statistic & Value & Signif. & $\mathbf{I}(\mathbf{0})$ & $\mathbf{I}(\mathbf{1})$ \\
\hline F-statistic & $5.904274^{* * *}$ & $10 \%$ & 1.99 & 2.94 \\
K & 6 & $5 \%$ & 2.27 & 3.28 \\
& & $2.5 \%$ & 2.55 & 3.61 \\
& & $1 \%$ & 2.88 & 3.99 \\
\hline
\end{tabular}

***** and ${ }^{*}$ denotes significant at $1 \%, 5 \%$ and $10 \%$ significance level, respectively, ARDL: Autoregressive distributed lag

MODEL II

The maximum lag length calculated using Akaike information criterion (AIC) based on the number of regressors included in the PCI model is 1 , just as it was for model I. As a result, the ARDL domestic investment (as measured by public corporation investment) model is ARDL (1, 0, 0, 0, 0, 0, 0). Table 4 illustrates that the null hypothesis of "no cointegration" can be rejected using the bounds test since the Fstat, 4.493017, is greater than the upper bound, I(1), at 1\% levels of significance. This demonstrates that domestic investment and all explanatory variables have a long-run link.

.Table 4. F-Bounds Test

\begin{tabular}{ccccc}
\hline Test Statistic & Value & Signif. & $\mathbf{I}(\mathbf{0})$ & $\mathbf{I}(\mathbf{1})$ \\
\hline F-statistic & $4.493017^{* * *}$ & $10 \%$ & 1.99 & 2.94 \\
K & 6 & $5 \%$ & 2.27 & 3.28 \\
& & $2.5 \%$ & 2.55 & 3.61 \\
& & $1 \%$ & 2.88 & 3.99 \\
\hline
\end{tabular}

***** and ${ }^{*}$ denotes significant at 1\%,5\% and 10\% significance level, respectively, ARDL: Autoregressive distributed lag.

\subsubsection{A Comparative Analysis of a Bounds Test: Model I and Model II Results.}

In both Model I and Model II, we used the ordinary least square (OLS) approach to estimate equation 3 and then computed the F-statistic for the null hypothesis $\beta_{1}=\beta_{2}=\beta_{3}=\beta_{4}=\beta_{5}=\beta_{6}=\beta_{7}=0$ versus the alternative $\beta_{1} \neq \beta_{2} \neq \beta_{3} \neq \beta_{4} \neq \beta_{5} \neq \beta_{6} \neq \beta_{7} \neq 0$. In the present of the long-run level relationship between domestic investment and all the explanatory variables. We reject the null hypothesis of "no cointegration" since the F-stats of Model I (5.904274) and Model II (4.493017) are both over the upper bound, (1) at 1\% significance levels. As a result, all the explanatory variables and domestic investment have a long-term association.

\subsection{Estimated Long Run and Short Run.}

Tables 5 and 6 indicate the domestic investment model's long and short run elasticities (as measured by credit to the private sector and public investment by public corporations) for South Africa. Panel 1 of the model shows the long run coefficients, whereas panel 2 shows the short run coefficients as well as the error correction coefficients.

\section{MODEL I}

The study calculates the ARDL (1, 1, 1, 0, 0, 0, 0) long- and short-run coefficients using the Schwarz Bayesian Criterion. According to Perasan et al. (1997: 3), the ARDL-Schwarz Bayesian Criterion and the ARDL-Akaike Information Criterion estimates have similar small-sample performances, with the ARDL- 
Schwarz Bayesian Criterion performing marginally better in the majority of the experiments, which could be due to the fact that the Schwarz Bayesian Criterion is a consistent model selection criterion while the Akaike Information Criterion is not.

Table 5. Long Run and Short Run Results for CPS.

\begin{tabular}{|c|c|c|c|c|}
\hline \multicolumn{5}{|l|}{ Panel 1: Long run } \\
\hline Variable & Coefficient & Std. Error & $\mathrm{t}$-Statistic & Pro. \\
\hline $\ln \mathrm{FDI}$ & -0.121050 & 0.106426 & -1.137412 & 0.2654 \\
\hline $\ln \mathrm{GINV}$ & 1.372965 & 2.567488 & 0.534750 & 0.5972 \\
\hline $\ln \mathrm{GDP}$ & -6.220620 & 17.405397 & -0.357397 & 0.7236 \\
\hline $\ln \mathrm{EXCR}$ & -453.2733 & 1974.716 & -0.229538 & 0.8202 \\
\hline $\ln \mathrm{SAV}$ & 5.450061 & 0.612180 & 8.902712 & $0.0000^{* * *}$ \\
\hline $\ln \mathrm{TRA}$ & -5.330410 & 1.914397 & -2.784380 & $0.0097^{* * *}$ \\
\hline $\mathrm{C}$ & 234120.5 & 630794.7 & 0.371152 & 0.7134 \\
\hline \multicolumn{5}{|l|}{ Panel 2: Short run } \\
\hline Variable & Coefficient & Std. Error & t-Statistic & Pro. \\
\hline$\Delta$ FDI & -0.207027 & 0.081775 & -2.531657 & $0.0175^{* *}$ \\
\hline$\Delta \mathrm{GINV}$ & 3.078544 & 1.397597 & 2.202741 & $0.0363^{* *}$ \\
\hline$\Delta \mathrm{GDP}$ & 4.900611 & 7.989686 & 0.613367 & 0.5448 \\
\hline$\triangle \mathrm{EXCR}$ & -662.3910 & 788.8127 & -0.839732 & 0.4084 \\
\hline$\triangle \mathrm{SAV}$ & 1.997824 & 0.401792 & 4.972289 & $0.0000^{* * *}$ \\
\hline$\Delta \mathrm{TRA}$ & -2.015385 & 0.411031 & -4.903240 & $0.0000^{* * *}$ \\
\hline $\operatorname{ECM}(-1)$ & -0.452335 & 0.058651 & -7.712334 & $0.0000^{* * *}$ \\
\hline R-squared & 0.827435 & \multicolumn{2}{|c|}{ Mean dependent var } & 78960.90 \\
\hline Adjusted R-squared & 0.796982 & \multicolumn{2}{|c|}{ S.D. dependent var } & 91.587 .65 \\
\hline S.E. of regression & 41267.07 & \multicolumn{2}{|c|}{ Akaike info criterion } & 24.24777 \\
\hline Sum squared resid. & $5.79 \mathrm{E}+10$ & \multicolumn{2}{|c|}{ Schwarz criterion } & 24.54033 \\
\hline Long likelihood & -490.0793 & \multicolumn{2}{|c|}{ Hannan-Quinn criter. } & 24.35430 \\
\hline Durbin-Watson stat & 1.704590 & & & \\
\hline
\end{tabular}

The long and short term link between FDI and CPS is shown in Table 5 panel 1 and panel 2. The results show that FDI and CPS have a negative relationship. In other words, a $1 \%$ increase in FDI will reduce CPS by 0.207027 in the short run and 0.121050 in the long run, respectively. The predicted outcome implies that, both in the short and long run, FDI crowds out domestic investment in South Africa. The findings are consistent with previous research by Aboye (2017), Morrissey and Udomkerdmongkol (2012), and Ashraf and Herzer (2014), which found that FDI crowds out domestic investment.

The estimated ADRL findings in panels 1 and 2 show a positive association between GINV and CPS, which is statistically significant at the $5 \%$ level in the short run. It's worth mentioning that a $1 \%$ rise in government investment expenditure (GINV) boosts domestic investment by 3.078544 percent in the short term and 1.372965 percent in the long term. This suggests that during the study period, GINV crowds in domestic investment in South Africa. The findings of AL-Abdulrazag (2009) and Alkhatib et al (2012), who identified a positive link between government and private investment, are consistent with this result. As a result, increased government infrastructure investment has a favorable influence on private domestic investment in South Africa.

Panel 1 shows that credit to private sector (CPS) has a negative association with economic growth (GDP). In the long run, a unit rise in economic growth (GDP) indicates that domestic investment (credit to 
private sector) will drop by 0.222614 unit. The finding implies that domestic investment is crowded out by GDP. When the GDP falls, firms are hesitant to expand their investment in the country since a drop in the GDP indicates that the national economy is experiencing challenges that are negatively affecting it. Our findings are in line with those of Elboiashi et al. (2009) and Lean and Tan (2010), who found that domestic investment had a negative impact on long-run economic growth. In the short run, however, GDP has a positive association with credit to private sector. In the short run, a unit increase in economic growth (GDP) entails a 4.900611 unit increase in domestic investment (credit to private sector).

The estimated long and short run coefficients for the real effective exchange rate (EXCR) are both negative. To put this in perspective, a one-unit rise in EXCR reduces domestic investment by 453.2733 units in the long run and by 662.3910 units in the short run. As a result, we can confirm that the real effective exchange rate, both in the short and long run, crowds out domestic investment in South Africa. This indicates that currency depreciation in South Africa does not boost domestic investment. This study is in line with Bakare's (2011) results, which found a negative link between the foreign exchange rate and private domestic investment in Nigeria. Furthermore, Dixit and Pindyck (1994) argued that higher exchange rate uncertainty reduces investment since investment projects are irreversible, and hence increases the value of deferring expenditures.

The estimated long and short run coefficients for gross domestic savings (SAV) have a positive relationship with CPS, as seen above. In other words, a 1\% rise in SAV will result in a 5.450061 percent increase in CPS in the long run and a 1.997824 percent increase in the short term. The preceding finding implies that gross domestic savings in South Africa crowd in domestic investment. This empirical conclusion is consistent with Verma's (2007) results, which show that gross domestic savings and gross domestic investment have a long-term association.

In South Africa, however, the estimated long and short run coefficients for Trade Openness are inversely associated to domestic investment. As a result of a unit rise in TRA, domestic investment falls by 5.330410 units in the long run and 2.015385 units in the short run. This suggests that trade openness hindered domestic investment. Trade openness has a negative impact on domestic investment because it increases foreign competition for homebased private investors, which has a negative impact on private investment. The findings are consistent with those of Bibi et al. (2012), who found that trade openness had a negative impact on domestic investment in Pakistan.

The error correction coefficient (ECM) has the right sign (negative) of -0.452335 , which is highly significant and shows a moderate speed of convergence, as shown in Table 6 panel 1. The Durbin-Watson value is 1.704590 , indicating that there are no autocorrelation problems. 
Model II.

The study estimates the ARDL $(1,1,1,0,0,0,0)$ long- and short-run coefficients using the Schwarz Bayesian Criterion.

Table 6. Long Run and Short Run Results for PCI.

\begin{tabular}{|c|c|c|c|c|}
\hline \multicolumn{5}{|l|}{ Panel 1: Long Run } \\
\hline Variable & Coefficient & Std. Error & $\mathrm{t}$-Statistic & Pro. \\
\hline $\ln \mathrm{FDI}$ & -0.039699 & 0.022999 & -1.726094 & $0.0958^{*}$ \\
\hline $\ln \mathrm{GINV}$ & 0.653690 & 0.515151 & 1.268928 & 0.2153 \\
\hline $\ln \mathrm{GDP}$ & 0.640266 & 3.239558 & 0.197640 & 0.8448 \\
\hline $\ln \mathrm{EXCR}$ & 223.1410 & 350.2860 & 0.637025 & 0.5295 \\
\hline $\operatorname{lnSAV}$ & 0.208785 & 0.078037 & 2.675470 & $0.0125^{* *}$ \\
\hline $\ln \mathrm{TRA}$ & -0.244041 & 0.240720 & -1.013795 & 0.3197 \\
\hline $\mathrm{C}$ & -65524.01 & 112962.4 & -0.580052 & 0.5667 \\
\hline \multicolumn{5}{|l|}{ Panel 2: Short Run } \\
\hline Variable & Coefficient & Std. Error & $\mathrm{t}$-Statistic & Pro. \\
\hline$\Delta$ FDI & -0.007304 & 0.010915 & -0.669170 & 0.5091 \\
\hline$\Delta \mathrm{GINV}$ & 0.133613 & 0.209292 & 0.638407 & 0.5286 \\
\hline$\Delta \mathrm{GDP}$ & -0.617483 & 1.190010 & -0.518889 & 0.6081 \\
\hline$\triangle \mathrm{EXCR}$ & -6.776037 & 117.5207 & -0.057658 & 0.9544 \\
\hline$\triangle \mathrm{SAV}$ & 0.102820 & 0.066106 & 1.555377 & 0.1315 \\
\hline$\triangle \mathrm{TRA}$ & -0.049743 & 0.064552 & -0.770594 & 0.4476 \\
\hline $\operatorname{ECM}(-1)$ & -0.382720 & 0.089735 & -4.265028 & $0.0002^{* * *}$ \\
\hline R-squared & 0.532579 & \multicolumn{2}{|c|}{ Mean dependent var } & 2155.098 \\
\hline Adjusted R-squared & 0.450093 & \multicolumn{2}{|c|}{ S.D. dependent var } & 8354.876 \\
\hline S.E. of regression & 6195.618 & \multicolumn{2}{|c|}{ Akaike info criterion } & 20.45532 \\
\hline Sum squared resid. & $1.31 \mathrm{E}+09$ & \multicolumn{2}{|c|}{ Schwarz criterion } & 20.74789 \\
\hline Long likelihood & -412.3341 & \multicolumn{2}{|c|}{ Hannan-Quinn criter. } & 20.56186 \\
\hline Durbin-Watson stat & 1.628138 & & & \\
\hline
\end{tabular}

Table 6 panel 1 and panel 2 show that the estimated long and short run variables of FDI are adversely connected to public corporation investment in South Africa. To put this in perspective, a $1 \%$ increase in FDI is estimated to reduce PCI by 0.039699 percent in the long run and 0.007304 percent in the short run. This means that foreign direct investment in South Africa crowds out domestic investment. This finding is in line with Morrissey and Udomkerdmongkol (2012) and Ashraf and Herzer (2014), who found that FDI crowds out domestic investment. According to Mileva (2008), FDI may crowd out domestic investment if MNCs raise productivity and drive domestic competitors out of the market. When MNCs employ imported inputs or enter industries formerly dominated by state-owned enterprises, this is frequently the case.

Furthermore, in South Africa, the estimate of GINV is positively associated to public corporation investment, implying that a $1 \%$ rise in GINV would result in a 0.653690 percent increase in public corporation investment in the long run and 0.133613 percent increase in the short run. As a result, we can confirm that government investment spending crowd in domestic investment. This conclusion is similar to that of Al khatib et al. (2012), who discovered a positive link between government and domestic investment. As a result, increased government infrastructure investment has a favorable impact on public corporation investment in South Africa. 
In the long run, economic growth (GDP) has a positive association with public corporation investment, as shown in Table 6 panel 1 of Model II. In the long run, a 1\% rise in GDP will result in a 0.640266 percent increase in public corporation investment. In the short run, however, the estimated GDP has a negative association with public corporation investment. Domestic investment (PCI) will decrease by 0.617483 units for every unit rise in GDP. The findings suggest that, in the short run, GDP crowds out domestic investment. This finding is in line with previous research by Elboiashi et al. (2009) and Lean and Tan (2010), which found that domestic investment had an adverse effect on economic growth.

In the long run, a real effective exchange rate (EXCR) and public corporation investment (PI) have a positive association. As a result of an increase in EXCR, public corporation investment will increase by 223.1410 units. This simply means that domestic investment is crowded in by the real effective exchange rate. The implication is that a currency devaluation in South Africa stimulates domestic investment. Imported resources and immediate goods become less expensive when the exchange rates increase. This conclusion is consistent with Zhang and Ward's (2015) research, which found that the real effective exchange rate is a key factor in influencing domestic investment. The estimated short run coefficient for the real effective exchange rate (EXCR) is, on the other hand, negative when it comes to public corporation investment. In the short run, this suggests that EXCR crowd out public corporation investment. This conclusion is in line with Bakare's (2011) previous results.

In the long and short run, gross domestic savings (SAV) has a positive relationship with public corporation investment. As a result, an increase in SAV would increase the value of public corporation investment (PCI) in the long run by 0.208785 and in the short run by 0.102820 . This demonstrates that gross domestic saving in South Africa crowds in domestic investment throughout the study period. This conclusion is in line with Verma's (2007) prior results, which showed that gross domestic savings and gross domestic investment have a long-term association.

The estimated trade openness (TRA) coefficient is inversely linked to public corporation investment. As a result, an increase in trade openness (TRA) will result in lower public corporation investment (PCI). The above result implies that in the long run, trade openness crowds out public corporation investment by -0.244041 and in the short run, by 0.049743 . This suggests that trade openness discourages domestic investment in South Africa. Our findings are consistent with those of Frimpong and Marbuah (2010), who found that trade openness in Ghana has a negative impact on domestic investment.

Finally, the error correction coefficient (ECM) in Table 6 panel 2 has the right sign (negative) of 0.382720 , which is highly significant and indicates a modest pace of convergence. The Durbin-Watson value is 1.628138 , indicating that there are no autocorrelation problems.

\subsubsection{A Comparative Analysis of a Long Run and Short Run Estimate: Model I and Model II Results.}

Finally, the error correction coefficient (ECM) in Table 6 panel 2 has the right sign (negative) of 0.382720 , which is highly significant and indicates a modest pace of convergence. The Durbin-Watson value is 1.628138 , indicating that there are no autocorrelation problems.

Table 5 and table 6 panel 1 show that the estimated long-run variable of FDI is negatively related to domestic investment in South Africa in both models. Both models had negative coefficients of 0.121050 and 0.039699. Table 5 and table 6 panel 1 show that the estimated long run variable of FDI is negatively related to domestic investment in South Africa. Both models had negative coefficients of 0.121050 and 0.039699 , respectively. This means that throughout the time period studied, FDI crowd out domestic investment in South Africa. Likewise, the ECM short run estimate revealed that FDI and domestic investment have a negative association. This result contradicts the theoretical benefits of FDI, which are that FDI is supposed to supplement domestic capital supply, allowing domestic investment projects to be funded more easily. Furthermore, it is suggested that FDI has a positive spillover impact on domestic investment in the host nation through knowledge transfer, leading to overall technological advancement and productivity 
spillovers in host countries. The findings, on the other hand, are consistent with those of Aitken and Harrison (1999), who claimed that the presence of FDI in a host country destabilizes the market equilibrium, forcing domestic firms to produce less output because fixed costs can only be spread over a smaller production, reducing their market shares.

Both in Model I and Model II, the long-run association between government investment expenditure and domestic investment is comparable. The coefficient reveals a positive link between government investment expenditure and credit to the private sector (CPS) and public corporation investment (PCI). Both models had positive coefficients of 1.372965 and 0.653690 , respectively. Similarly, both models show a constant and positive long-run link between government investment expenditure and domestic investment. As a result of this finding, government investment expenditures crowd in domestic investment. The infrastructure was built not just to serve individuals and residents, but also to serve the business community (both private and public enterprises), and it is unquestionably one of Africa's greatest infrastructures.

Both in Model I and Model II, the long-run relationship between economic growth (GDP) and domestic investment is inconclusive. In model I, the coefficient shows a negative relationship between economic growth and credit to the private sector (CPS), whereas in model II, the coefficient shows a positive relationship between economic growth and public corporation investment (PCI). In model I, this simply means that economic growth in South Africa crowds out credit to the private sector, whereas economic growth crowds in public corporation investment. Both models had long run negative and positive coefficients of 0.222614 and 1.037534, respectively. In Model I and Model II, the short-run relationship between GDP and domestic investment is also inconsistent. In the short run, GDP crowds in credit to the private sector, whereas public corporation investment crowds out GDP. For both models, the short run positive and negative coefficients were 4.900611 and 0.617483 , respectively.

In both Model I and Model II, the long-run link between the real effective exchange rate and domestic investment is inconclusive. In model I, the estimated coefficient indicates that EXCR has a negative association with credit to the private sector (CPS). In other words, the real effective exchange rate has a negative impact on credit to the private sector. The estimated coefficient, on the other hand, demonstrates that under Model II, the real effective exchange rate has a positive association with public corporation investment. In other words, the real effective exchange rate has a favorable impact on domestic investment. The implication is that in Model I, real effective exchange rates crowd out credit to the private sector by 453.2733, but in Model II, real effective exchange rates crowd in public corporation investment by 223.1410. Both Model I and Model II agree on the short-run link between real effective exchange rate and domestic investment. In models I and II, the real effective exchange rate crowds out domestic investment. The negative coefficients in the short run were 662.3910 and 6.776037, respectively.

In both Model I and Model II, the long-run connection between gross domestic savings and domestic investment is stable. The coefficients demonstrated a favorable link between gross domestic saving and domestic investment (as measured by credit to private and public corporation investment). Both models had coefficients of 5.450061 and 0.102820, respectively. Similarly, in both Model I and Model II, the shortrun connection between gross domestic savings and domestic investment is constant. In the long and short run, the outcome implies that gross domestic savings crowd in domestic investment in South Africa. Domestic investment, it is believed, has a tactical role to play since capital formation happens when the host country's domestic cycle of production, income, and savings is in place. As a result, the ability to build domestic capital implies the presence of a stable economic environment. These findings support Odhiambo's (2009) assertion that as saving grows, domestic investment grows, and a rise in domestic investment leads to an increase in real income, especially in developing nations. Similarly, Girma (2017) suggested that domestic saving is the primary driver of domestic investment growth, which is necessary for rapid and long-term economic growth. 
In both Model I and Model II, the long and short run relationship between trade openness and domestic investment is consistent. Trade openness has a negative relationship with credit to the private sector (CPS) and public corporation investment, according to the coefficient (PCI). In the long run, the coefficients for both models were 5.330410 and 0.244041 , respectively, whereas in the short run, the coefficients were 2.015385 and 0.049743 . This simply means that trade openness stifles domestic investment. This also implies that trade openness has a lesser role in increasing domestic investment in South Africa by increasing exports and making importing intermediate, capital products, and new technologies much simpler, all of which encourage investment in the country.

The ECM term's negative symbol represents the expected long-run convergence process, as well as less than one and significant. The ECM coefficients for both models were -0.452335 and -0.382720 , showing a high speed of adjustment and a highly significance level for ECM at the $1 \%$ level.

\subsection{Diagnostic tests.}

Finally, as shown in Table 7 and Figure 1, the ARDL model passed all diagnostic tests. These tests demonstrate that the model is correctly specified and that parameter estimations are not biased. To check for autocorrelation in the model, the Breusch-Godfrey Serial LM test was performed. The LM is used to test the null hypothesis that no serial correlation exists. The Breusch-Godfrey Lagrange Multiplier Tests were also used to check for serial autocorrelation among the estimated variables. The test's null hypothesis is that there is no serial association. The null hypothesis cannot be rejected since the p-value for the JarqueBera statistic for the model indicated that the residuals have no serial correlation greater than 0.05 .

Table 7. Residual Analysis Results

\begin{tabular}{lcccc}
\hline & CPS MODEL I & & PCI MODEL II \\
\hline \multicolumn{1}{c}{ Tests } & Values & P-values & Values & P-values \\
\hline Breusch-Godfrey Serial LM & 0.877234 & 0.3490 & 1.065401 & 0.3020 \\
Breusch-PaganGodfrey's Heteroskedasticity & 17.84402 & 0.0719 & 6.110384 & 0.5269 \\
Jarque-Bera & 2.156619 & 0.340170 & 2.905507 & 0.233925 \\
\hline
\end{tabular}

Source: Author's Computation

The CUSUM is used to test the models' structural stability. At a 5\% significant level, the findings are within the critical boundaries, showing that the model is stable, consistent, and dependable (Figure 1). Over the sample period 1975-2016, the CUSUM plots demonstrate that the long-run coefficients and the shortrun coefficients in ECM are stable and effect domestic investment.

Figure 1: Stability Test: CUSUM

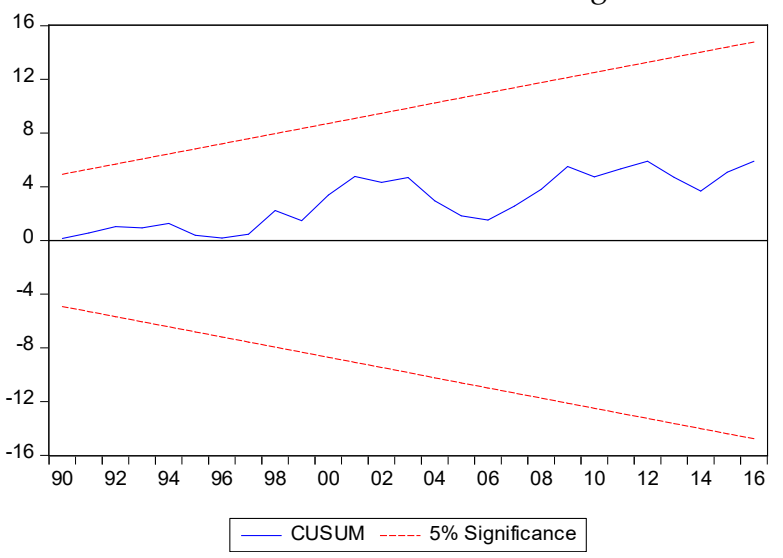

(a) MODEL I

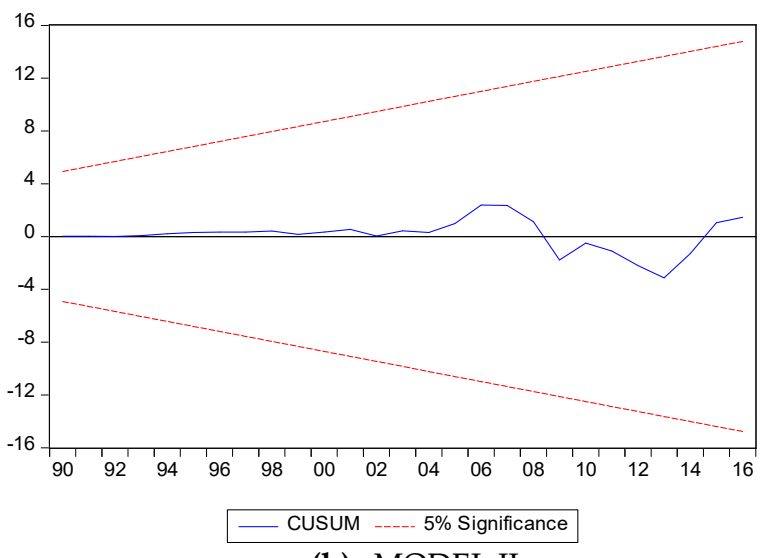

(b) MODEL II 


\section{Conclusion}

Using the ARDL bounds test, this article examines the underlying link between FDI and domestic investment in South Africa from 1975 to 2016. This paper is unique in that it focuses on the decomposition of domestic investment into private domestic investment and public domestic investment. The impact of foreign direct investment on domestic investment is equivocal, according to the empirical literature. However, over the time period studied, this article indicates that foreign direct investment in South Africa crowd out domestic investment. This means that the net benefits of foreign direct investments are not really automatic, and their magnitude varies depending on the host country and context. Low levels of education, low-tech local industries, macroeconomic policy uncertainty, political instabilities, and insufficient regulatory frameworks are among the factors that prevent these FDI from fully bearing fruit in some developing countries, such as South Africa. Domestic investment, on the other hand, according to Firebaugh (1992), is more likely to foster relationships within domestic industries.

To determine the order of integration of the series under consideration, the manuscript employed well-known PP unit root testing method to evaluate the series' stationarity. After initial differencing, the unit root result implies that all variables were stationary. As a result, all of the series are integrated of order I(1), except CPS, FDI, and SAV, which are integrated of order I. (0). The ARDL technique, on the other hand, can handle integer or fractional order of integration and does not make the restrictive assumption that all of the variables under investigation must be integrated in the same order, allowing it to avoid testing the order of integration of variables.

The selection of appropriate optimal lags for both models was critical before we computed the ARDL. The maximum lag length chosen by Akaike information criterion (AIC) based on the number of regressors included in the domestic investment (as measured by credit to private sector) model is 1 , so ARDL (1, 1, 1, $0,0,0,0)$ was obtained for model I, while ARDL $(1,0,0,0,0,0,0)$ was obtained for domestic investment (as measured by public corporations investment) model in model II. The F-statistic for the first model was 5.904274, while the F-statistic for the second model was 4.493017, both of which were higher than the Narayan (2005) table's upper bounds value (3.99) at the 1\% level of significance. In both model I and model II, the results show a negative association between FDI and domestic investment (credit to the private sector and public corporation investment). This simply means that credit to private sector and public corporation investment in South Africa is crowded out by FDI. The conclusion is that foreign direct investment has no influence on domestic investment in South Africa, and that FDI actually crowds out domestic investment. According to Kholdy, (1995), FDI places a burden on host countries, such as greater competition pressure on domestic firms, crowding out effect on domestic investment, and deterioration of the balance of payment due to profit repatriation.

Furthermore, in South Africa, the long-term estimate of government investment expenditure (GINV) is positively connected to domestic investment (both domestic private and public corporation investment). In the long and short run, the result implies that government investment expenditure crowds out domestic investment in South Africa. The conventional wisdom holds that government expenditure pushes out domestic private investment. It is stated that more government expenditure, whether funded through taxes or debt, boosts demand for goods and services, driving interest rates to rise, making domestic capital more costly and, as a result, lowering domestic private investment. When the economy's resources are stagnant or underutilized, crowding in of investment happens. This may happen in South Africa, where government infrastructure spending, for example, can encourage private investment.

In both Model I and Model II, the long-run link between the real effective exchange rate and domestic investment is inconclusive. In model I, the long run estimate revealed that the real exchange rate (EXCR) has a negative relationship with credit to the private sector. In Model II, however, the EXCR has a negative relationship with public corporation investment. This simply means that in Model I, EXCR crowds out private-sector finance, but in South Africa, EXCR crowds in public-sector investment. In addition, the short 
run estimate revealed that EXCR had a negative association with private sector credit in Model I and public corporation investment in Model II.

In both Model I and Model II, the long and short run association between gross domestic savings and domestic investment is comparable. The coefficients demonstrated a favorable link between gross domestic saving and domestic investment (as measured by credit to private and public corporation investment). In the long and short run, the outcome implies that gross domestic savings crowd in domestic investment in South Africa.

In both Model I and Model II, the long and short run link between trade openness and domestic investment is constant. Trade openness has a negative link with credit to the private sector (CPS) and public corporation investment, according to the coefficient (PCI). This means that during the study period, trade openness crowded out domestic investment in South Africa. This also implies that trade openness plays a lesser influence in increasing South Africa's domestic investment levels.

The ECM coefficient is -0.383103 for model I and -0.317640 for model II, indicating the speed with which short run fluctuations are adjusted to long run equilibrium (38 percent and 32 percent discrepancy is corrected each year), and approximately 38 percent and 32 percent of disequilibrium from the previous year's shock convergence back to the long run equilibrium in the current year. 


\section{References}

Aboye, YY. 2017. Nexus between Foreign Direct Investment and Domestic Investment in Ethiopia: Crowding-in/out Effects. Journal of Economics and Sustainable Development, 8(1), 36-46.

Adams, Samuel. 2009. Foreign direct investment, domestic investment, and economic growth in SubSaharan Africa. Journal of Policy Modeling, 31(6) 939-949.

Agosin, MR and Machado, R. 2005. Foreign investment in developing countries: does it crowd in domestic investment? Oxford Development Studies, 33 (2), 149- 162.

Aiken, B.J, and Harrison, A. 1999. Do Domestic Firms Benefit from Direct Foreign Investment? Evidence from Venezuela. The American Economic Review, 89(3), 605-618.

Al khatib, H. B., Altaleb, G. S. and Alokor, S. M. 2012. Economical Determinants of Domestic Investment. European Scientific Journal, 8(7), 1-17.

AL-Abdulrazag, BA. 2009. The Impact of Public Investment on Private Investment in Jordan. DirasatAdministrative Sciences, 36 (2), 528-540.

Alfaro, L., Chanda, A., Kalemli-Ozcan, S., Sayek, S., 2006. How Does Foreign Direct Investment Promote Economic Growth? Exploring the Effects of Financial Markets on Linkages. National Bureau of Economic Research.

Alkhatib, HB., Altaleb, GS., and Alokor, SM. 2012. Economical Determinants of Domestic Investment. European Scientific Journal, 8 (7), 1-17.

Al-Sadig, A., 2013. The effects of foreign direct investment on private domestic investment: evidence from developing countries. Empir. Econ. 44, 1267-1275.

Ang, JB., 2009. Do public investment and FDI crowd in or crowd out private domestic investment in Malaysia? Applied Economics. 41, 913-919.

Apergis, N., C. Katrakilidis, and N. Tabakis. 2006. Dynamic linkages between FDI inflows and domestic investment: A panel cointegration approach. Atlantic Economic Journal, 34 (4): 385-394.

Ashraf, A and Dierk Herzer,D. 2014. The effects of Greenfield investment and M\&As on domestic investment in developing countries, Applied Economics Letters, 2014, 21 (14), 997-1000

Badri Narayan Rath, and Debi Prasad Bal. 2014.Do FDI and Public Investment Crowd in or Crowd out Private Domestic Investment in India. The Journal of Developing Areas, 48(3), 269-284

Baek, J., 2016. A new look at the FDI-income-energy-environment nexus: dynamic panel data analysis of ASEAN. Energy Policy 91, 22-27.

Bakere, A.S. 2011. A theoretical analysis of capital formation and growth in Nigeria. Far East Journal of Psychology and Business, 3(1), 12-24.

Bibi, S., Khan, U. A., and Bibi, A. 2012. Determinants of Investment in Pakistan. Academic Research International, 2 (2), 517-524.

Blomstrom, M and Kokko, A 1998. "Multinational corporations and spillovers. Journal of Economic survey,.12, 247-278.

Bosworth, BP, Susan MC, and Carmen MR.1999. Capital flows to developing economies: implications for saving and investment, Brookings papers one economic activity, (1), 143-180.

Caves, R. 1974. Multinational Firms, Competition and Productivity in the Host Country. Economica 41: 176193.

Chang, S. C. 2010. Estimating relationships among FDI inflow, domestic capital, and economic growth using the threshold error correction approach. Emerging Markets Finance and Trade, 46, 6-15 
Cristina J. 2015. Does FDI Crowd out Domestic Investment in Transition Countries? LEO Working Papers / DR LEO 2301, Orleans Economics Laboratory / Laboratoire d'Economie d'Orleans (LEO), University of Orleans.

Cristina, J .2016. Technology Spillovers from FDI. Evidence on the Intensity of Different Spillover Channels. The World Economy, 39(12), 1947-1973.

Dixit, A.K., \& Pindyck, R.S. 1994. Investment under Uncertainty, Princeton University

Elboiashi, H., Noorbakhsh, F., Paloni, A. and Azemar, C. 2009. The causal relationships between foreign direct investment (FDI), domestic investment (DI) and economic growth (GDP) in North African nonoil producing countries: empirical evidence from cointegration analysis. Advances in Management, 2(11), pp. 19-25.

Engle, RF., Granger, C.W.J., 1987. Co-Integration and error correction: representation, estimation, and testing. Econometrica 55, 251-276.

Farla, K, Denis de C, and Bart V.2014. Institutions, Foreign Direct Investment, and Domestic Investment: crowding out or crowding in? World Development.

Fedderke, JW., and Romm, AT. 2005. Growth Impact and determinants of foreign direct investment into South Africa. University of Cape Town. Working Paper: 12.

Findlay, R. 1978. Relative Backwardness, Direct Foreign Investment and the Transfer of Technology: A Simple Dynamic Model. Quarterly Journal of Economics 92: 1-16.

Firebaugh, G. 1992. Growth Effects of Foreign and Domestic Investment. American Journal of Sociology, 98, 105-130. http://dx.doi.org/10.1086/229970

Frimpong, JM., and Marbuah, G. 2010. The Determinants of Private Sector Investment in Ghana: An ARDL Approach. European Journal of Social Sciences, 15 (2), 250-261.

Girma, G. 2017. Trends and Determinants of Gross Domestic Saving in Ethiopia, Journal of Economics and Sustainable Development, 8(5),72-81.

Görg, H. and Greenway, D. 2001. Foreign direct investment and intra-industry spillovers: a review of the literature. GEP.

Gungor, H. and Ringim, SH. 2017. Linkage between Foreign Direct Investment, Domestic Investment and Economic Growth: Evidence from Nigeria. International Journal of Economics and Financial Issues, 7(3), 97-104.

Harrison, AE., Love, I. and MS. McMillan 2004. Global capital flows and financing constraints". Journal of Development Economics, 75, 269-301

Hirschman, A. 1958. The Strategy of Economic Development. New Haven: Yale University Press.

Hymer, Stephen 1960. The International Operations of National Firms: A Study of Foreign Direct Investment, Massachusetts Institute of Technology: MIT Press.

Ivanović , I. 2015. Impact Of Foreign Direct Investment (FDI) On Domestic Investment In Republic Of Croatia. Review of Innovation and Competitiveness, 1(1).

Jan Mišun, Vladimr Tomšk. 2014. Does Foreign Direct Investment Crowd in or Crowd out Domestic Investment? Eastern European Economics, 40:2, 38-56: http://dx.doi.org/10.1080/00128775.2002.11041015.

Javorcik, B.S. 2004. Does Foreign Direct Investment increase the productivity of domestic firms? In search of spillovers through backward linkages. American Economic Review, 94

Jude, C. 2016. Technology Spillovers from FDI. Evidence on the Intensity of Different Spillover Channels. The World Economy, 39(12), pp. 1947-1973. 
Kholdy, S. 1995. Causality between foreign investment and spillover efficiency, Applied Economics, 27:8, 745749, DOI: $10.1080 / 00036849500000064$

Kojima, K. 1973. A macro- economic approach to foreign direct investment. Hitotsubasi journal of Economics 14

Kokko, A. 1994. Technology, Market Characteristics and Spillovers. Journal of Development Economics 43: 279-293.

Lall, S. 1980. Vertical interfirm linkages in LDCs: An empirical study. Oxford Bulletin of Economics and Statistics, 42 201-223.

Leamer, EE. 1988. Measures of Openness, University of Chicago Press, ss.145-204.

Lean, HH, and Tan, BW. 2011. Linkages between foreign direct investment, domestic investment and economic growth in Malaysia. Journal of Economic Cooperation \& Development, 32 (4): 75

Liu Zhiqiang, 2008. Foreign direct investment and technology spillovers: Theory and evidence. Journal of Development Economics, 85,176-193.

Mansfield, E. and Romeo, A., 1980. Technology Transfer to Overseas Subsidiaries by U.S.-Based Firms. Quarterly Journal of Economics 95 (4), pp. 737-750.

Markusen. J. and Venables, A. J. 1999. Foreign Direct Investment as a Catalyst for Industrial Development. European Economic Review 43(2), 335-356.

Mileva, E. 2008. The Impact of Capital Flows on Domestic Investment in Transition Economies. European Central Bank. Working Paper Series No 871.

Morrissey, O and Udomkerdmongkol, M. 2012. Governance, private investment and foreign direct investment in developing countries, World development, 2012, 40 (3), 437-445.

Narayan, PK. 2005. The saving and investment nexus for China: evidence from cointegration tests. Applied Economics, 37(17), 1979-1990.

Ndikumana, L., and Verick, S. 2008. The linkages between FDI and domestic in-vestment: Unravelling the developmental impact of foreign investment in Sub-Saharan Africa. Development Policy Review, 26(6), 713-726.

Nunnenkamp, P., and J. Spatz. 2003. Foreign Direct Investment and Economic Growth in Developing Countries: How Relevant Are Host-Country and Industry Characteristics? Kiel Institute for World Economics.

Odhiambo, N M. 2009. Saving and Economic growth in South Africa, A multivariate causality test. Journal of Policy Modeling, 31, 798-718. http://dx.doi.org/10.1016/j.jpolmod.2009.04.001

Olatunji, LA and Shahid, MS. 2015. Determinants of FDI in Sub-Saharan African Countries: A Review of the Evidence. Business and Economic Research, 5 (2), 62-91

Olise, MC., Anigbogu, TU., and Okoli MI. 2013. Domestic Investment and Foreign Direct Investment in Nigeria. Journal of Humanities and Social Science, 13(6), 1-12.

Onyinyechi, OC., and Ekwe, MC. 2017. Impact of Foreign Direct Investment (FDI) on the Stock Market Performances in Nigeria (1985-2014), Applied Finance and Accounting, 3(1), 36-48.

Paolino, Michael. 2009. The Effect of Domestic Investment, Economic Growth and Human Development on Foreign Direct Investment into China. Bryant Economic Research Paper 2.11.

Pesaran, M.H. \& Shin, Y. 1996. Cointegration and the speed of convergence to equilibrium. Journal of Econometrics, 71: $117-43$. 
Pesaran, M.H., Shin, Y., Smith, R.J. 2001. Bounds testing approaches to the analysis of level relationships. Journal of Applied Econometrics, 16(3), 289-326.

Pesaran, MH., Smith, R.P., 1998. Structural analysis of cointegrating VARs. J. Econ.Surv. 12, 471-505.

Rodriguez-Clare, A. 1996. Multinationals, Linkages and Economic Development. American Economic Review, 86: 852-873.

Sağlam, B.B and Yalta, A.Y. 2011. Dynamic linkages among foreign direct investment, public investment and private investment: Evidence from Turkey. Applied Econometrics and International Development, 11, 71-82.

SARB. 2017. FDI Inflows by Country and Industry. South African Reserve Bank, Quarterly Bulletin March 2017.

Shawa, M.J. and Amoro, G. 2014. The causal link between foreign direct investment, GDP growth, domestic investment and export for Kenya: The new evidence. Journal of Economic and Sustainable Development, 5(16), 107-115.

Tan, B. and Tang, C. 2016. Examining the Causal Linkages among Domestic Investment, FDI, Trade, Interest. International Journal of Economics and Financial Issues, 2016, 6(1), 214-220.

Tang, S, Selvanathan, EA and Saroja, S. 2008. Foreign direct investment, domestic investment and economic growth in China: a time series analysis, The World Economy, 31 (10), 1292-1309.

Ullah, I., Shah, M. and Khan, UF. 2014. Domestic Investment, Foreign Direct Investment, and Economic Growth Nexus: A Case of Pakistan. Economics Research International, 1-5.

United Nations Conference on Trade and Development (UNCTAD). 2017. Global Investment Trends Monitor, United Nations Publications, Geneva, Switzerland

Verma, R. 2007. Savings, Investment and Growth in India: An Application of the ARDL Bounds Testing Approach. South Asia Economic Journal, 8, 87-98. https://doi.org/10.1177/139156140600800105.

Wang, M. 2010. Foreign direct investment and domestic investment in the host country: evidence from panel study. Appl. Econ. 42, 3711-3721.

Xu, G and Wang, R. 2007. The effect of foreign direct investment on domestic capital formation, trade, and economic growth in a transition economy: Evidence from China. Global Economy Journal, 7, 1-21

Yen, DTH. 2008. The Impacts of Trade Liberalization to Economic Growth with the Case of Vietnam, http://www.grips.ac.jp/vietnam/VDFTokyo/Doc/42DTHYen26Apr08Slides.pdf

Zhang, J and Ward, T. 2015. Assessing the Impacts of Capital Inflows on Domestic Economy across the Sub-Saharan Africa Countries. International Economic Journal, 29(3), 375-397. https://doi.org/10.1080/10168737.2015.1020325. 